九州大学学術情報リポジトリ

Kyushu University Institutional Repository

\title{
A Cytotoxic Subcellular Fraction of Mouse Spleen Extract
}

Momi i, Akira

Laboratory of Pesticide Chemistry, Faculty of Agriculture, Kyushu University

Maekawa, Kazuyuki

Laboratory of Pesticide Chemistry, Faculty of Agriculture, Kyushu University

Eto, Morifusa

Laboratory of Pesticide Chemistry, Faculty of Agriculture, Kyushu University

https://doi.org/10.5109/23698

出版情報: 九州大学大学院農学研究院紀要. 24 (2/3)，pp.81-92，1979-11. Kyushu University バージョン：

権利関係 : 


\title{
A Cytotoxic Subcellular Fraction of Mouse Spleen Extract
}

\author{
Akira Momii*, Kazuyuki Maekawa** \\ and Morifusa Eto \\ Laboratory of Pesticide Chemistry, Faculty of Agriculture. \\ Kyushu University 46-02, Fukuoka 812
}

(Received June 4, 1979)

\begin{abstract}
This paper deals with screening and partial purification of a cytotoxic substance from the spleen of mice resistant to the Ehrlich ascites tumor. The purification was performed by a fractionation with ammonium sulfate, sucrose density-gradient centrifugation, and isoelectric focusing electrophoresis. The cytotoxicity was recovered in the microsomal fraction of the spleen extract. Thus, it was concluded that the cytotoxic substance was not humoral.
\end{abstract}

In order to elicit tumor resistance in host animals, two methods have been employed mainly, that is, inoculation of attenuated tumor cells (Révész, 1960 ; Buzzi and Buzzi, 1974 ; Morgan and Eng, 1972; Kato et al., 1972) and immunopotentiation by host-mediated adjuvants (Old et al., 1961; Chihara et al., 1970; Grohsman and Nowotny, 1972; Lindenmann, 1974; Kato et al., 1973; Likhite and Halpern, 1973).

In research for tumor immunology, transplantation immunity with nonspecific transplantable tumors has been adopted as a model of tumor immunity (Lindenmann, 1974).

A complex (MA: y-RNA), composed of methylated bovine serum albumin (MA) and yeast RNA (y-RNA), attenuated Ehrlich ascites tumor cells (E-cells) by being transferred into their cytoplasm by endocytosis (Maekawa and Kushibe, 1972). Mice inoculated with the attenuated tumor cells could reject the following challenges of the intact cells (Maekawa and Kushibe, 1969; 1972).

Killer T-cells and humoral mediators, lymphokines, released from the cells have been assumed to take an important role in cellular immunity which mainly contributes to tumor resistance (Mitchison, 1955; David, 1971). Furthermore, subcellular components which mediate the tumor resistance were also recognized in peripheral lymphoid tissues or lymphocytes (Clewell et al., 1969; Fraser and Cater, 1972; Ferluga and Allison, 1975).

The present paper deals with screening and partial purification of a cytotoxic substance from the spleen of the E-cell resistant mice.

* Present address: The Rockefeller University, New York 10021

** Present address: Fukuoka Junior College of Social Work and Child Education, Tagawa 825 


\section{MATERIALS AND METHODS}

\section{Cells and Mouse}

E-cells were maintained in the peritoneal cavity of the ddN mouse which was supplied by the Animal Center at Kyushu University. One fifth $\mathrm{ml}$ of ascitic fluid containing the tumor cells (about $10^{8}$ cells per ml) was transferred from mouse to mouse weekly. Other cells used were Sarcoma-180 cells, FM3A (cell line derived from mammary tumor of the C3H mouse), TBV (cell line from W/Fu rat leukemia) and normal ddN mouse spleen cells. FM3A and TBV, kindly supplied by Dr. H. Okano of the Kyushu Cancer Center, were cultured in RPMI-1640 supplemented with calf serum (Research Institute for Microbial Disease, Osaka University) up to $5 \%$ in a sealed TD 40 tissue culture bottle (Ikemoto Rikaki, Ltd.) at $37^{\circ} \mathrm{C}$. Normal mouse spleen cells were prepared as follows. Spleens of the ddN mouse killed by cervical dislocation were washed with VBS (veronal buffered saline) and minced finely with scissors. The minced tissues were further dissociated by the shearing force developed by 2 pieces of slide glass, suspended in $10 \mathrm{ml}$ of VBS and allowed to stand in a test tube till blocks of the tissues fell down. The supernatant without the blocks was washed with VBS 3 times. All these procedures were carried out at $4^{\circ} \mathrm{C}$.

\section{Mouse resistant to E-cells}

An MA: y-RNA complex was prepared as described previously (Maekawa and Kushibe, 1972). MA was purchased from the Miles Laboratories Inc. (Elkhart, Ind., U. S. A.) or was prepared by esterification of bovine serum albumin fraction V (Sigma Chemical Co., St. Louis, Mo., U. S. A.) by Fraenke1Conrat's method (Fraenkel-Conrat and Olcott, 1945). Yeast RNA (Sigma Chemical Co.) was further purified by the method reported previously (Maekawa and Kushibe, 1964). To a female mouse $10^{5}$ of E-cells incubated with $6.0 \mathrm{mg}$ of the complex at $25^{\circ} \mathrm{C}$ for 20 minutes were inoculated intraperitoneally. The mouse was challenged 3 times with $2 \times 10^{5}$ of intact E-cells at 20 day intervals intraperitoneally.

Spleen extract and its fractionation

Spleens obtained from the mice resistant to E-cells and/or from normal mice of the same age were frozen and thawed several times. Then, the spleens were minced and further ruptured with the rotating homogenizer pestle in 2 volumes of $\mathrm{PBS}(-)\left(\mathrm{Ca}^{2+}, \mathrm{Mg}^{2+}\right.$-free phosphate buffered saline). The homogenate was centrifuged at $10,000 \mathrm{rpm}$ for 30 minutes with a IB rotor (Sakuma Seisakusho, Ltd.). The resulting precipitate was homogenized again in 2 volumes of $\mathrm{PBS}(-)$ and centrifuged under the same conditions. The supernatants (spleen extract) were put together and added $\left(\mathrm{NH}_{4}\right)_{2} \mathrm{SO}_{4}$ up to $30 \%$ saturation. The resulting precipitate was collected by centrifugation, suspended in PBS(-) and dialyzed against the saline. The dialyzate was centrifuged at $10,000 \mathrm{rpm}$ for 30 minutes and cytotoxicity of the supernatant was assayed. The obtained fractions are referred to R-I-a from the resistant mouse spleens and N-I-a from the normal ones. Furthermore, the spleen 
extract was ultracentrifuged at $45,000 \mathrm{rpm}$ for 1 hour with a RP 55 rotor (Hitachi Seisakusho, Ltd.). The precipitate and the fluffy layer was homogenized in a small amount of $\mathrm{PBS}(-)$ and ultracentrifuged again. The precipitate was suspended in PBS(-) by homogenization and centrifuged at $10,000 \mathrm{rpm}$ for 30 minutes. The resulting supernatant was added $\left(\mathrm{NH}_{4}\right)_{2} \mathrm{SO}_{4}$ up to $30 \%$ saturation. The precipitating fraction was collected by centrifugation, suspended in PBS(-) and dialyzed against the saline. The dialyzate was centrifuged at $10,000 \mathrm{rpm}$ for 30 minutes and the cptotoxicity of the supernatant was assayed. The obtained fractions are referred to RP-30 from the resistant mouse spleens and NP-30 from the normal ones.

\section{Cytotoxicity test}

E-cells harvested from the peritoneal cavity of the mouse were washed with PBS (-) or VBS several times and the concentration was adjusted to 8 $\times 10^{7}$ cells per $\mathrm{ml}$. One-hundredth $\mathrm{ml}$ of the cell suspension and $0.5 \mathrm{ml}$ of the spleen extract or its subfraction were mixed and incubated at $37^{\circ} \mathrm{C}$ for 2 hours with successive shaking in duplicate test tubes. Dead cells were stained with $1.5 \mathrm{ml}$ of $0.4 \%$ nigrosin solution in saline. Evaluation of the cell number was carried out on a Bürkel-Türk hematometer. Specific activity was represented as reciprocal of absorbance at $280 \mathrm{~nm}$ of the preparation which resulted in $50 \%$ of dead cells. Total activity was given as a product of the specific activity and total absorbance (the absorbance times volume) of the spleen extract or its subfraction.

\section{Sucrose density gradient centrifugation}

On $0.5 \mathrm{ml}$ of $60 \%$ sucrose solution $27.5 \mathrm{ml}$ of linear density gradient sucrose solution (from 35 to $5 \%$ ) and $2.0 \mathrm{ml}$ of RP-30 or NP-30 preparation were layered in order. The sucrose was dissolved in PBS(-). Centrifugation was carried out at 25,000 rpm for 2 hours with SW 25.1 rotor (Beckman Instrument, Inc.). After centrifuged, the content in the centrifuge tube was divided into 40 fractions $(0.75 \mathrm{ml}$ in each fraction tube). The cytotoxicity of each fraction, whose absorbance at $280 \mathrm{~nm}$ was adjusted to 1.0, was assayed. The active region was arbitrarily divided into 3 subfractions (I, II and III).

\section{Isoelectric focusing of the cytotoxic subfractions}

The cytotoxic subfractions obtained by the sucrose density gradient centrifugation were dialyzed against 2 liter of $10 \mathrm{mM} \mathrm{NaCl}$ solution for 2 days with 3 changes of the solution. The dialyzates were filtered through a prefilter AP 25 type (diameter: $13 \mathrm{~mm}$, Millipore Corp., Bedford, Mass., U.S.A.). The filtrates were subjected to isoelectric focusing at 1 to $2^{\circ} \mathrm{C}$ for 48 hours by Svensson's method (Vesterberg and Svensson, 1966). Anti-convection agents used were $50 \%$ sucrose or $60 \%$ glycerin solution. Concentration of carrier ampholyte (LKB, Stockholm, Sweden) was $1.0 \%$. After the separation was over, the content in the column was fractionated by $1.8 \mathrm{ml}$ portion in each fraction tube. Absorbance at $280 \mathrm{~nm}$ and $\mathrm{pH}$ of each fraction were measured.

\section{Enzyme-treatment of the cytotoxic fraction}

The cytotoxic fraction RP-30 was treated with bovine pancreatic RNase A 
or Streptomyces griseus protease (Sigma Chemical Co.). RNase A was dissolved in PBS(-) (10 mg per $\mathrm{ml}$ ) and dialyzed against the saline overnight. The enzyme activity was determined by Koga's method (Koga et al., 1967). The protease was dissolved in PBS( -) (20 mg per $\mathrm{ml}$ ) and centrifuged at 10,000 rpm for 30 minutes. The supernatant was also dialyzed. The dialyzate was centrifuged again if necessary. The proteolytic activity was determined after Hagiwara (Hagiwara, 1961).

The enzyme solution $\left(5 \times 10^{3}\right.$ units and $1.3 \times 10^{4}$ units per $\mathrm{ml}$ of the protease and the RNase $A$, respectively) was mixed with an equal volume of RP-30 preparation and the mixture was incubated at $37^{\circ} \mathrm{C}$ for 30 and 60 minutes. After the incubation, the mixture was heated in boiling water for 5 minutes to inactivate the enzymes, and subjected to the cytotoxicity test. In the control experiment, RP-30 preparation was incubated at $37^{\circ} \mathrm{C}$ without the enzymes and then heated in boiling water. The cytotoxic factor did not alter its activity by heating in boiling water as shown in Fig. 1.

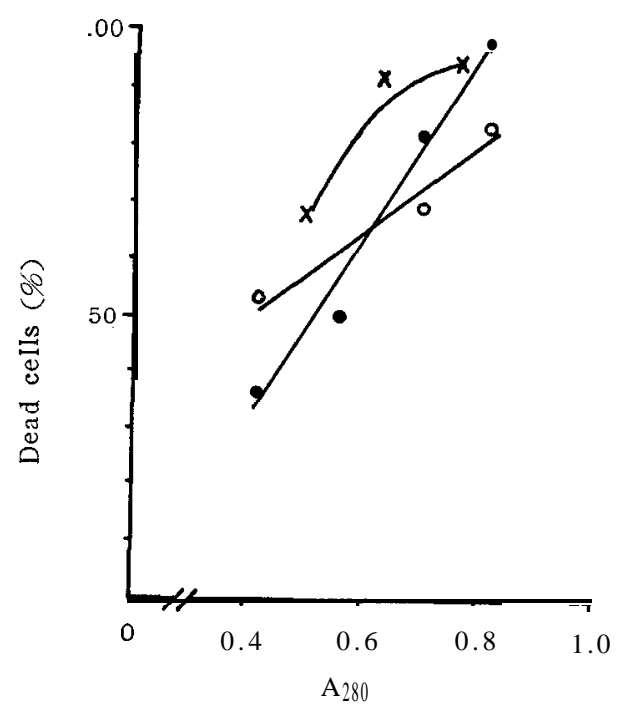

Fig. 1. Thermostability of cytotoxic factor.

$\mathrm{RP}-30$ heated at $100^{\circ} \mathrm{C}$ for $5(x)$ and 30 minutes (0). Untreated RP-30(•).

\section{RESULTS}

The cytotoxicity was recognized in both $\mathrm{R}-\mathrm{I}-\mathrm{a}$ and $\mathrm{N}-\mathrm{I}-\mathrm{a}$ preparations. Both had an equal extent of the cytotoxicity as shown in Fig. 2. However, the weight of one resistant mouse spleen was $0.18 \mathrm{~g}$ (average of 675 spleens), whereas that of one normal mouse spleen was $0.14 \mathrm{~g}$ (average of 511 spleens). So the total activity of $\mathrm{R}-\mathrm{I}-\mathrm{a}$ and $\mathrm{N}-\mathrm{I}-\mathrm{a}$ preparations obtained from one mouse was 26.1 and 18.6, respectively.

The specific and the total activity of the normal mouse spleen extract, 


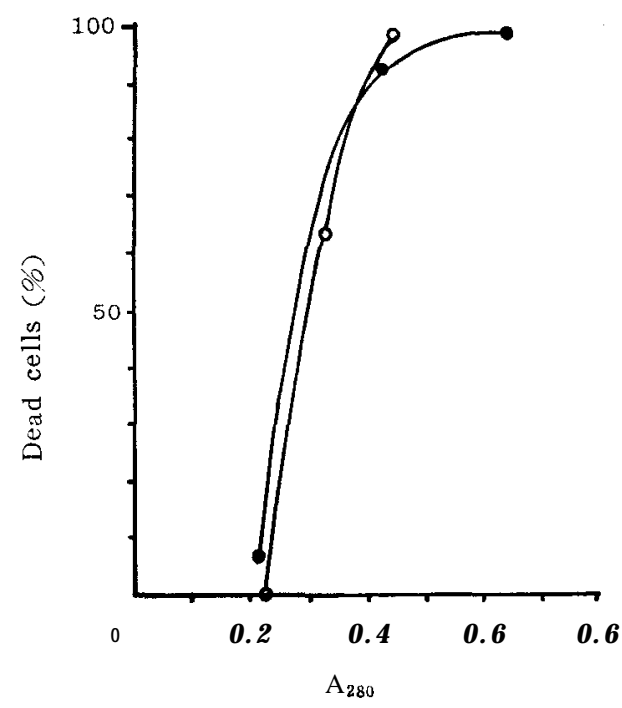

Fig. 2. Cytotoxicity of active fractions from spleens of mice resistant to E-cells, R-I-a $(-\bullet)$, and those of normal ones, N-I-a (-o-).

Table 1. Cytotoxic activity of normal mouse spleen extract and its subfractions.

\begin{tabular}{l|llc}
\cline { 3 - 4 } \multicolumn{1}{c}{ Fraction } & \multicolumn{1}{c}{$\begin{array}{c}\text { Specific } \\
\text { activity }\end{array}$} & $\begin{array}{c}\text { Total } \\
\text { activity }^{2)}\end{array}$ \\
\hline $\begin{array}{l}\text { Spleen ext. } \\
\text { Dialyzed spleen ext. }\end{array}$ & $\begin{array}{lll}0.015(1.0)^{3)} \\
\text { N-I-a }\end{array}$ & $0.98(14.0)$ & 10.8 \\
\hline
\end{tabular}

1) The reciprocal of absorbance at $280 \mathrm{~nm}$ that gave $50 \%$ of dead cells

2) The product of the specific activity and the total absorbance of the preparation.

3) The specific activity of the spleen extract was defined as 1.0.

and its active fractions were shown in Table 1. The spleen extract had so slight cytotoxicity that the intact extract could kill only about a half of the cells in the incubation mixture. However, when the extract was dialyzed against PBS(-) overnight, the specific and the total activity arose up to 14 and 10 times, respectively. It is, therefore, suggested that dialyzable substance(s) suppress the cytotoxicity in the spleen extract.

The cytotoxicity was recovered in the microsomal fraction of the spleen extract, so it is concluded that the cytotoxic substance is not humoral. This was confirmed by the sucrose density gradient centrifugation.

The result of the sucrose density gradient centrifugrtion is shown in Fig. 3. The relative activity was almost constant from the fraction number 10 to 29. Dilute sucrose solution less than 20 \% in PBS(-) was not cytotoxic during the 2 hours' incubation. So, each fraction whose concentration of sucrose 


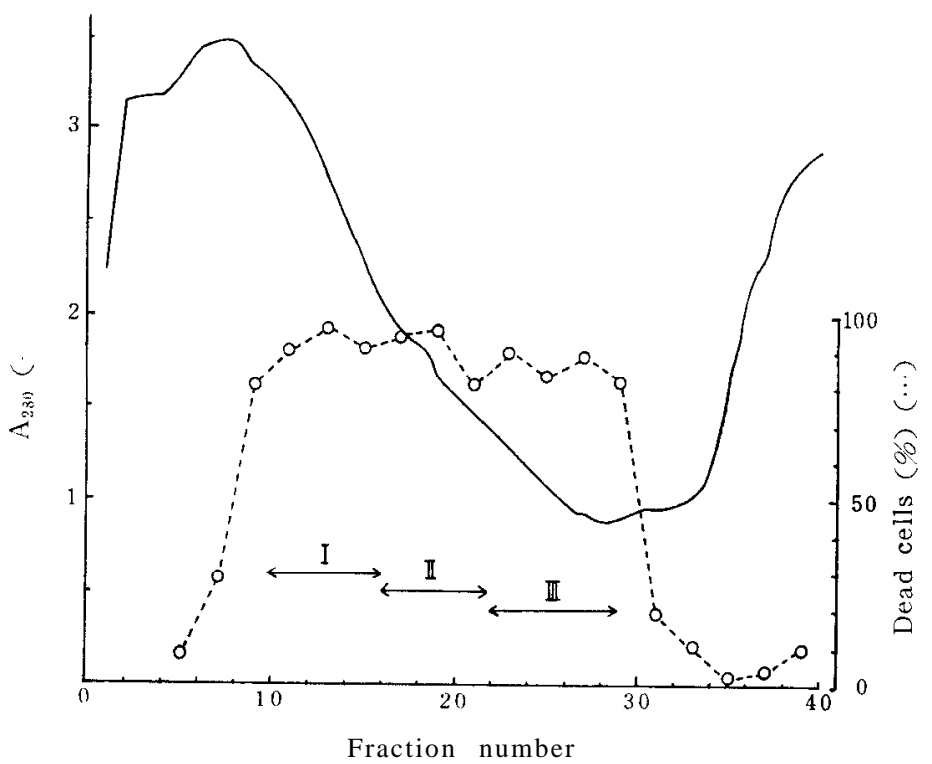

Fig. 3. Sucrose density-gradient centrifugation of the KP-30

Rotor : SW-25.1, Centrifugation : 25,000 rpm. 2 hrs., Sucrose density gradient: $35-5 \%(0.5 \mathrm{ml}$ of $60 \%$ sucrose solution was laid at the bottom of the tube). 13 drops were collected in each fraction tube.

was diluted to less than $20 \%$ was subjected to the cytotoxicity test. Sedimentation constant of the cytotoxic substance was calculated to be 400 to 70 $S$ by Martin's equation (Martin and Ames, 1961), when the partial specific volume of the sedimentating particle was provided to be $0.725 \mathrm{~cm}^{3}$ per $\mathrm{g}$ (Van Holde, 1975).

The isoelectric focusing patterns of the cytotoxic subfractions obtained by the sucrose density gradient centrifugation were shown in Fig. $4 \mathrm{a}-\mathrm{b}-\mathrm{c}$ respectively. The precipitate appeared near the position of $\mathrm{pH} 4.7$ in all the subfractions and this part alone was active (indicated by dotted area). Although these subfractions (I, II, and III) were still impure, their amino acid compositions were preliminary estimated in order to acquire some clews to the further purification. The results were shown in Table 2 and in a topographic Chart (Fig. 5).

As seen from Fig. 5, their amino acid compositions were surprisingly close each other. Therefore, it is presumed that the active principles may be composed of cohesively similar unit.

The cytotoxic activity in RP-30 preparation was diminished by treatment with Streptomyces griseus protease, as shown in Fig. 6. However, RNase A did not alter the cytotoxic activity as shown in Fig. 7.

The inhibitory effect on transplantability of E-cells was observed in N-I-a preparation when a higher dose was administered (Maekawa et al., 1978). All the mice looked well through the experiment.

The cytotoxic fraction was also effective on not only E-cells but also 


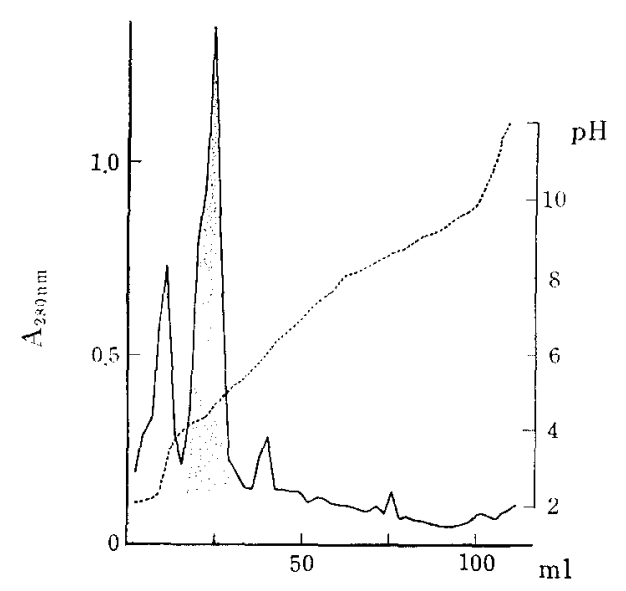

Fig. J-a. Isoelectric focusing of the fraction I. Anti-convection agent was 509 sucrose solution. Voltage : $230-78$ V ; Current: $4 \mathrm{~mA}-1.4 \mathrm{~mA}$; Sample charged, $16.5 \mathrm{ml}$ (total $A_{,,,,,}=12$ )

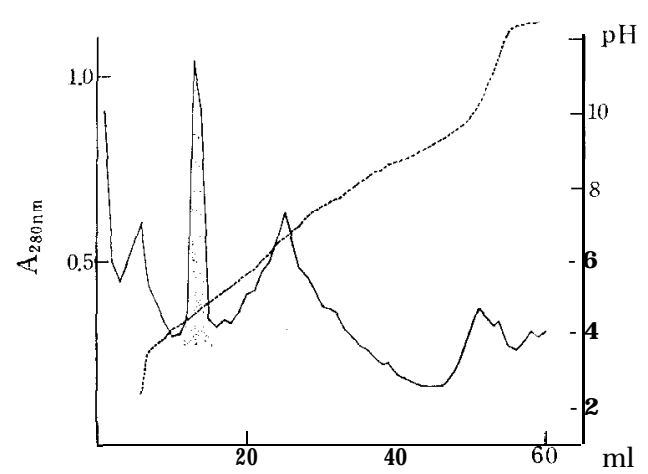

Fig. 4-b. Isoelectric focusing of the fraction II. Anti-convection agent was $60 \%$ glycerin solution.

other cells such as FM3A, TBV, Sarcoma-180 cells and normal mouse spleen cells (Table 3 ).

\section{DISCUSSION}

Factors that mediate various physiological phenomena in the field of tumor immunology are actively being investigated by many workers. Especially, the presence of cytotoxic substances is assumed to be concerned in host's tumor resistance (Meltzer and Bartlett, 1972; Vaillier et al., 1972; Luzzio, 1973). Although these substances were reported to be humoral, the cytotoxic factor in this investigation is found not to be humoral by the ultracentrifugation technique and the sucrose density gradient centrifugation. Ferluga reported 


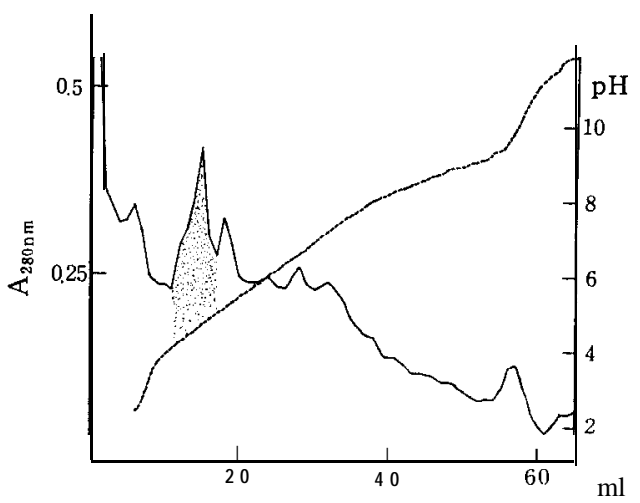

Fig. 4-c. Isoelectric focusing of the fraction III. Anti-convection agent was $60 \%$ glycerin solution.

Table 2. Amino acid composition of the fraction I

\begin{tabular}{|c|c|c|}
\hline Amino acid & $\mu$ mole & $\mu \mathrm{g}$ \\
\hline Lys & 0.0206 & 2.641 \\
\hline $\mathrm{His}$ & 0.0074 & 1.015 \\
\hline Arg & 0.0193 & 3.015 \\
\hline Asp & 0.0303 & 3.458 \\
\hline $\mathrm{Thr}$ & 0.0184 & 1.861 \\
\hline Ser & 0.0225 & 1.960 \\
\hline Glu & 0.0354 & 4.537 \\
\hline Pro & 0.0158 & 1.535 \\
\hline Gly & 0.0239 & 1.364 \\
\hline Ala & 0.0276 & 1.962 \\
\hline Val & 0.0202 & 2.003 \\
\hline Met & 0.0005 & 0.066 \\
\hline I $1 \mathrm{k}$ & 0.0151 & 1.709 \\
\hline Leu & 0.0343 & 3.882 \\
\hline Tyr & 0.0074 & 1.208 \\
\hline Phe & 0.0133 & 1.958 \\
\hline \multicolumn{2}{|c|}{ Total ( $\mu \mathrm{g})$} & 38.043 \\
\hline \multicolumn{2}{|c|}{ Recovery $\%$} & 48.63 \\
\hline
\end{tabular}

that the cell membrane fraction from oxazolone-activated lymphoid tissue had cell-injuring action which was not due to contaminant of the humorallymphotoxin (Ferluga and Allison, 1975). Fraser and Cater (1972) showed that sedimentable subcellular components from lymphoid tissue of mouse sensitized with allogeneic tumor had a therapeutic effect against the same tumor in syn. geneic host. The cytotoxic activity in this investigation may also be contributed by cell membrane fragments, which were obtained by homogenization of the spleen to be fragmented to 70 to $400 \mathrm{~S}$ particles.

The dose-response curve of the cytotoxicity had a steep slope. It is, therefore, assumed that certain amount of the active particle is necessary for the cell to be killed. The amount of the cytotoxic activity in a resistant mouse was 1.4 times higher than that in a normal one. This fact may indi- 


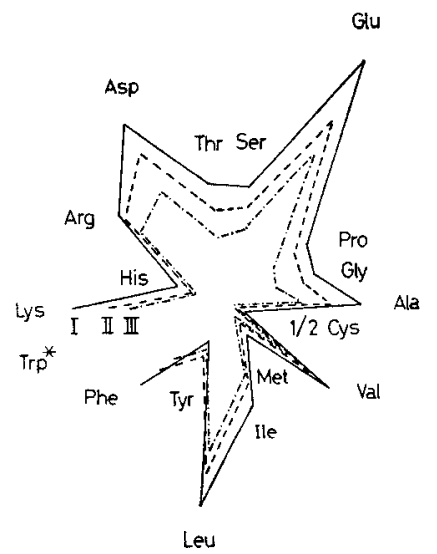

Fig. 5. Comparison of amino acid compositions of the fraction I, II, and III.

* remain to be estimated

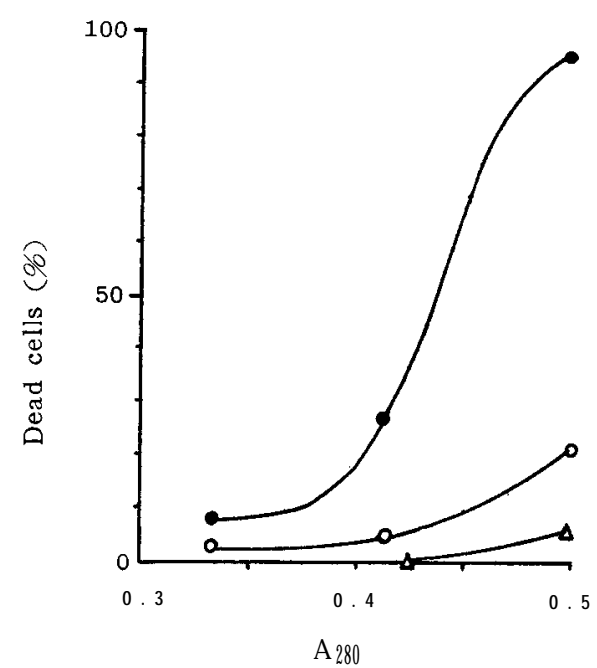

Fig. 6. Protease-sensitivity of cytotoxic factor.

KP-30 treated with protease from Streptomyces griseus at $37^{\circ} \mathrm{C}$ for $30 \mathrm{~min}$. (o) and $60 \mathrm{~min}$. (A). Control (•).

cate that a certain amount of the cytotoxic factor is also necessary for the host to reject the tumor transplanted.

All the cytotoxic subfractions by the sucrose density gradient centrifuga. tion were found to be similar to one another in the isoelectric focusing pattern. Especially, all of them contained a major component that was precipitated near the $\mathrm{pH}$ 4.7. The effluent from the column was fractionated into several portions and dialyzed against PBS(-) with 5 changes of the saline, and the cytotoxicity of the dialyzates was assayed. Only the fraction obtained 


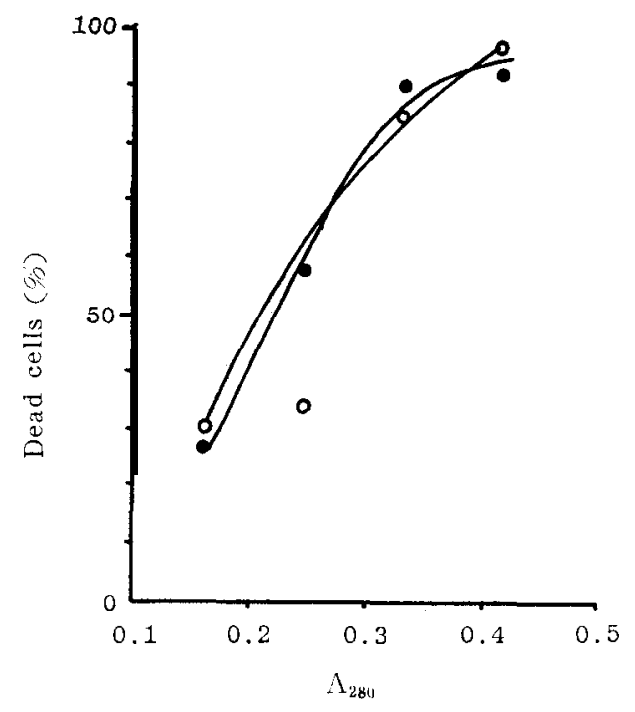

Fig. 7. Stability of cytotoxic factor against ribonuclease $A$. RP-30 incubated with RNase A at $37 \mathrm{C}$ for $60 \mathrm{~min} .(0)$. Control (•).

Table 3. Cytotoxicity of RP-30 preparation on cells other than E-cells.

\begin{tabular}{|c|c|c|}
\hline Cells & $\begin{array}{l}\text { Conc. of } \\
\text { RP-301) }\end{array}$ & $\begin{array}{c}\text { Dead cells } \\
(\%)\end{array}$ \\
\hline Sarcoma- 180 & $\begin{array}{l}0.547 \\
0.684\end{array}$ & $\begin{array}{l}89.1 \\
99.5\end{array}$ \\
\hline FM3A & 0.250 & 97.8 \\
\hline Normal spleen cells & 0.333 & 100 \\
\hline TBV & 3.2 2) & 100 \\
\hline
\end{tabular}

1) Represented by the absorbance at $280 \mathrm{~nm}$.

2) At this concentration, $44.9 \%$ of E-cells was died.

from the region near $\mathrm{pH} 4.7$ could represent the slight activity (14.9\% of dead cells with the absorbance 0.392 in the case of the subfraction II). When R-l- a and N-I-a preparations were dialyzed against McIlvaine's buffer ( $\mathrm{pH}$ 5.0) for three hours, precipitate appeared in the dialyzate. The supernatant of the dialyzate showed no cytotoxicity. However, the precipitate, dissolved in 0. $1 \mathrm{M} \mathrm{Na}_{2} \mathrm{HPO}_{4}-\mathrm{NaOH}$ buffer ( $\mathrm{pH}$ 11.0) and dialyzed against $\mathrm{PBS}(-)$ for 24 hours with 3 changes of the saline, showed 1.3 times stronger activity than the parent fraction. Recovery of the total activity in the precipitate was 95 $\%$. No lowering of the cytotoxicity was recognized when the cytotoxic preparation was dialyzed against $0.1 \mathrm{M} \mathrm{Na}_{2} \mathrm{HPO}_{4}-\mathrm{NaOH}$ buffer (pH 11.0) for 6 
hours. As the isoelectric focusing system in this experiment contained a slight of $\mathrm{NaCl}$, the exact isoelectric point of the components was not determined. From these results, however, it is assumed that the isoelectric point of the cytotoxic factor is near 4.7.

The cytotoxicity was affected by treatment with the protease from Streptomyces griseus, but was not diminished by pancreatic RNase A. From these results, it is concluded that the cytotoxic activity is mediated by a protease. sensitive substance or protein.

\section{REFERENCES}

Buzzi, S. and L. Buzzi 1974 Cancer immunity after treatment of Ehrlich tumor with Diphtheria toxin. Cancer Res., 34: 3481-3486

Chihara, G., J. Hamuro, Y. Maeda. Y. Arai and F.Fukuoka 1970 Fractionation and purification of the polysaccharides with marked antitumor activity, especially lentinan, from Lentinus edodes (Berk.) Sing. (an edible mushroom). Cancer Res., 30: 2776-2781

Clewell, D. B., J. D. Hubbard, P.-L. Yu, L. C. Yip and M. E. Hodes 1969 Fractionation of spleen and serum in attempts to isolate the radiation-leukemia protection factor. Cancer Res., 29: 1333-1340

David, J. R. 1971 Immunobiology. rd. by R. A. Good and D. W. Fisher, Sinauer Associates Inc., Stanford, Conn.

Ferluga, J. and A. C. Allison 1975 Cytotoxicity of isolated plasma membranes from lymphnode cells. Nature, 255: 708-710

Fraenkel-Conrat, H. and H. S. Olcott 1945 Esterification of proteins with alcohols of low molecular weight. J.Biol.Chem., 161: 259-268

Fraser, L. B. and D. B. Cater 1972 Protection by subcellular reactions prepared from lymph-nodes and spleens of specifically allergized C57 B1 mice against fatal challenge with BP 8 ascites tumor cells in C3H mice. Brit. J. Exp. Pothol., 53: 98-110

Grohsman, J. and A. Nowotny 1972 The immune recognition of TA 3 tumors, its facilitation by endotoxin, and abrogation by ascites fluid. J.Immunol., 109: 1090-1094

Hagiwara, B. 1961 Koso Kenkyu Ho, Vol. 11, ed. by S. Akabori, Asakura Shoten, Tokyo

Kato, N., S. Ito and D. Mizuno 1972 Induction of resistance against Ehrlich carcinoma by tumor cells sensitized with immunized rabbit serum. Gann, 63: 173-179

Kato, N., S. Ito, M. Yamazaki and D. Mizuno 1973 Effect of Proteus vulgarislipopolysaccharide on resistance of mice inoculated with tumor cells sensitized to Ehrlich carcinoma transplantation. Gann, $64: 111-120$

Koga. K., J. Mukai and S. Akune 1967 Purification and properties of acid ribonucleases from posterior silk gland of silkworm. J. Insect Physiol., 13: 1885-1894

Likhite, V. V. and B. N. Halpern 1973 The delayed rejection of tumors formed from the administration of tumor cells mixed with killed Corynebacteriunz parvum. Znt. J. Cancer, 12 : 699-704

Lindenmann, J. 1974 Viruses as immunological adjuvants in cancer, Biochem. Biophys. Acta. 355: 49-75

Luzzio, C. B. 1973 Cytotoxicity of a factor isolated from human spleen. J. Nat. Cancer Inst., 50: 535-538

Maekawa, K. and M. Kushibe 1964 Antigens associated with ribvnucleic acid. Agric. Biol. Chem, $28: 686-689$

Maekawa, K. and M. Kushibe 1969 Studies on the inhibition to propagation of Ehrlich ascites tumor. Proc. Japan Acad., 45: 298-302 
Maekawa, K. and M. Kushibe 1972 Repression of propagation of Ehrlich ascites tumors by means of attenuating tumor cells. Cancer. 30: 366-372

Maekawa. K., A. Momii and K. Kuwano 1978 Cytocidal activity existing in tissues of animals and its characterization. In "Prevention and detection of cancer", Part 1, ed. by H. E. Nieburgs, N. Y. Marcel Dekker, Inc, pp. 1779-1788

Martin, R. G. and B. N. Ames 1961 A method for determining the sedimentation behaviors of enzymes: Application to protein mixtures. J. Biol.Chem., 236: 1372-1379

Meltzer, M. S. and G. L. Bartlett 1972 Cytotoxicity in vitro by products of specifically stimulated spleen cells: Susceptibility of tumor cells and normal cells. $J$. Nut. Cancer Inst., 49 : 1439-1443

Mitchison, N. A, 1955 Studies on the immunological response to foreign tumor transplants in the mouse. J.Exp. Med., 102, 157-177

Morgan, J. F. and C. P. Eng 1972 The induction of immunoprotection by mouse ascites tumor cells attenuated in tissue culture. Eur. J. Cancer, 8: 293-298

Old. L. J., B. Benacerraf, D. A. Clarke, E. A. Carswell and E. Stockert 1961 The role of the reticuloendothelial system in the host reaction to neoplasia. Cancer Res.. 21: 12811300

Révész, L. 1960 Detection of antigenic differences in isologous host-tumor systems by pretreatment with heavily irradiated tumor cells. Cancer Res. 20: 443-451

Vaillier. D., M. Donner and C. Burg 1972 Release of a cytotoxic factor by murine spleen cells in the presence of a tumour allograft. Experientia, 28: 1352-1353

Van Holde. K. E 1975 The proteins (3rd ed.). Vol. 1, ed. by II. Neurath and R. L. Hill, Academic Press, New York, p. 263

Vesterberg. 0. and H. Svensson 1966 Isoelectric fractionation, analysis, and characterization of ampholytes in natural pH gradients. Actu Chem.Scand., 20: 820-834 